\title{
ЗАКОНОМЕРНОСТИ ЗАГРЯЗНЕНИЯ МАЛЫХ ПРИТОКОВ РЕКИ ВОЛГА
}

\author{
Мазуркин П.М., д-р тех. наук, проф., акад. РАЕН, \\ Марийский государственный технический университет, г. Йошкар-Ола, \\ E-mail: kaf_po@mail.ru
}

По данным гидрометрических, гидрологических и санитарно-эпидемиологических измерений можно выявлять закономерности многолетних, годичных, сезонных, месячных, недельных и суточных переменных циклов и волновых колебательных возмущений.

При этом закономерности загрязнения в основном зависят от весеннего половодья.

Динамика весеннего половодья. Многие виды загрязнения во времени изменяются также как и уровень воды в реке [1]. Поэтому выявление закономерностей годичной динамики нужно начать с весеннего половодья [2] для прогнозов на следующий год. Второй этап годичной динамики происходит от начала весеннего половодья (включая весенний ледоход в несколько дней) до летней межени. По данным [1] примем шкалу времени $t$ с началом $t=0$ на дату 24.03.1975. По исходным данным из указанного практикума [1] была получена статистическая модель по методу [3] (рис. 1 и рис. 2) уровня реки $y$ (см) реки

$$
\begin{gathered}
y=y_{1}+y_{2}+y_{3}+y_{4}+y_{5}+y_{6}+y_{7}, \\
y_{1}=91,2336 \exp \left(-0,071156 t^{1,05457}, y_{2}=34,0562 t^{3,86623} \exp \left(-1,93001 t^{0,51643}\right),\right. \\
y_{3}=-1,3352 \cdot 10^{-12} t^{6,65073}, y_{4}=A_{1} \cos \left(\pi t / p_{1}-2,76469\right), \\
A_{1}=2,7882 \cdot 10^{-7} t^{7,75145} \exp \left(-0,19030 t^{1,08516}\right), p_{1}=9,22100+2,9729 \cdot 10^{-5} t^{2,70730}, \\
y_{5}=A_{2} \cos \left(\pi t / p_{2}+2,85526\right), A_{2}=3,5590 \cdot 10^{+10} t^{56,34772} \exp \left(-58,66859 t^{0,41062}\right), \\
p_{2}=0,091646+0,018181 t^{1,16879}, y_{6}=A_{3} \cos \left(\pi t / p_{3}-1,61374\right), \\
A_{3}=1,39351 \exp \left(0,039080 t^{0,78581}\right), p_{3}=4,35033+0,00085582 t^{1,31011}, \\
y_{7}=A_{4} \cos \left(\pi t / p_{4}-1,64872\right), A_{4}=2,18017 \exp (-0,0062142 t), p_{4}=-14,4021+16.60491 t^{0,019922}, \\
\text { где: } A-\text { амплитуда колебания уровня реки, см; } p \text { - половина периода волны колебания, сутки. }
\end{gathered}
$$

Первая составляющая показывает естественный процесс спада стока воды при условии, что этот спад происходит без последующей подпитки осадками с площади водосбора. Наиболее значимой является вторая составляющая стрессового возбуждения реки в весеннее половодье. Третья составляющая является вспомогательной, зависящей от принятия начала координат. Тогда тренд содержит три не волновые составляющие.

Полный период одной длины волны увеличивается со временем по всем четырем колебательным составляющим модели (1). Поэтому чем раньше начнется половодье, то тем он чаще и резче колеблется по уровню реки. Можно также отметить, что в конкретном примере первые две волны возмущения имеют выпуклую амплитуду, третья волна распространяется на осень, а четвертая амплитуда показывает спад в конце прошлого года. 


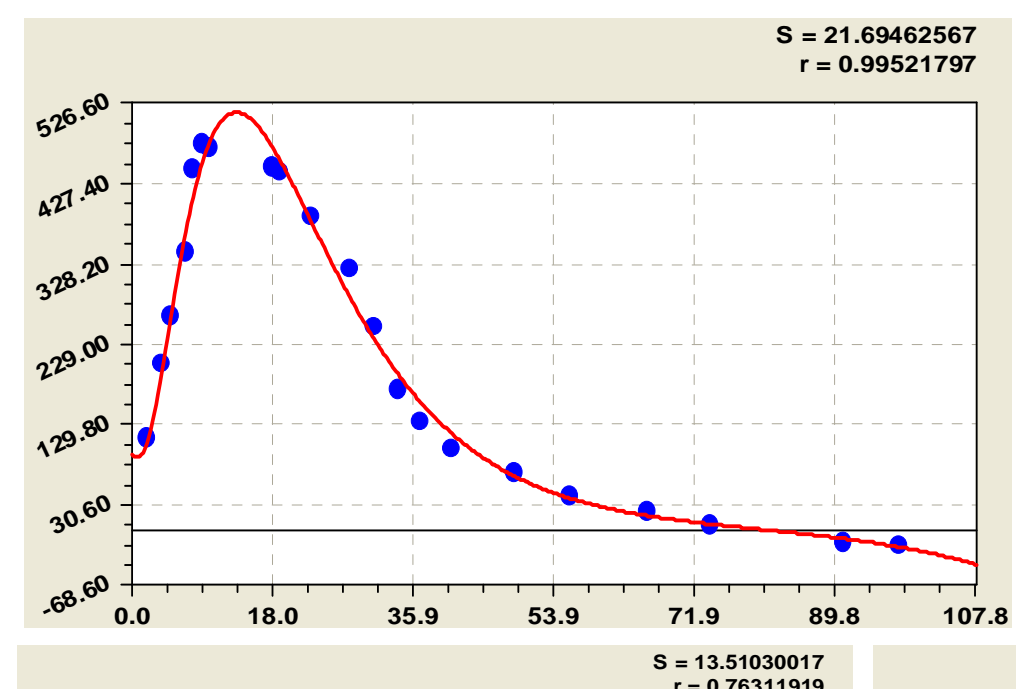

Рис. 1. Тренд по первым трем составляющим модели (1)

Из-за высокой точности при коэффициенте корреляции 0,9952 уравнение (1) вполне может заменить табличную модель [1] изменения уровня воды в реке, например, при прогнозировании весеннего половодья в имитационных моделях.

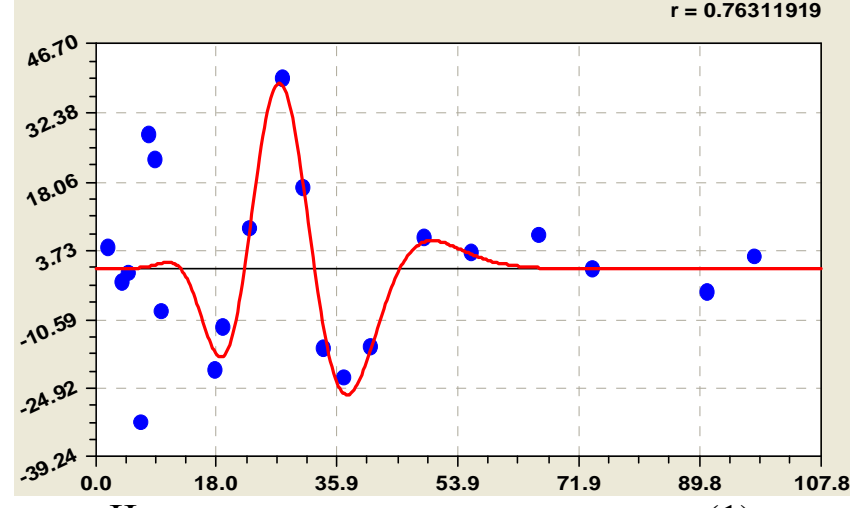

Четвертая составляющая модели (1)
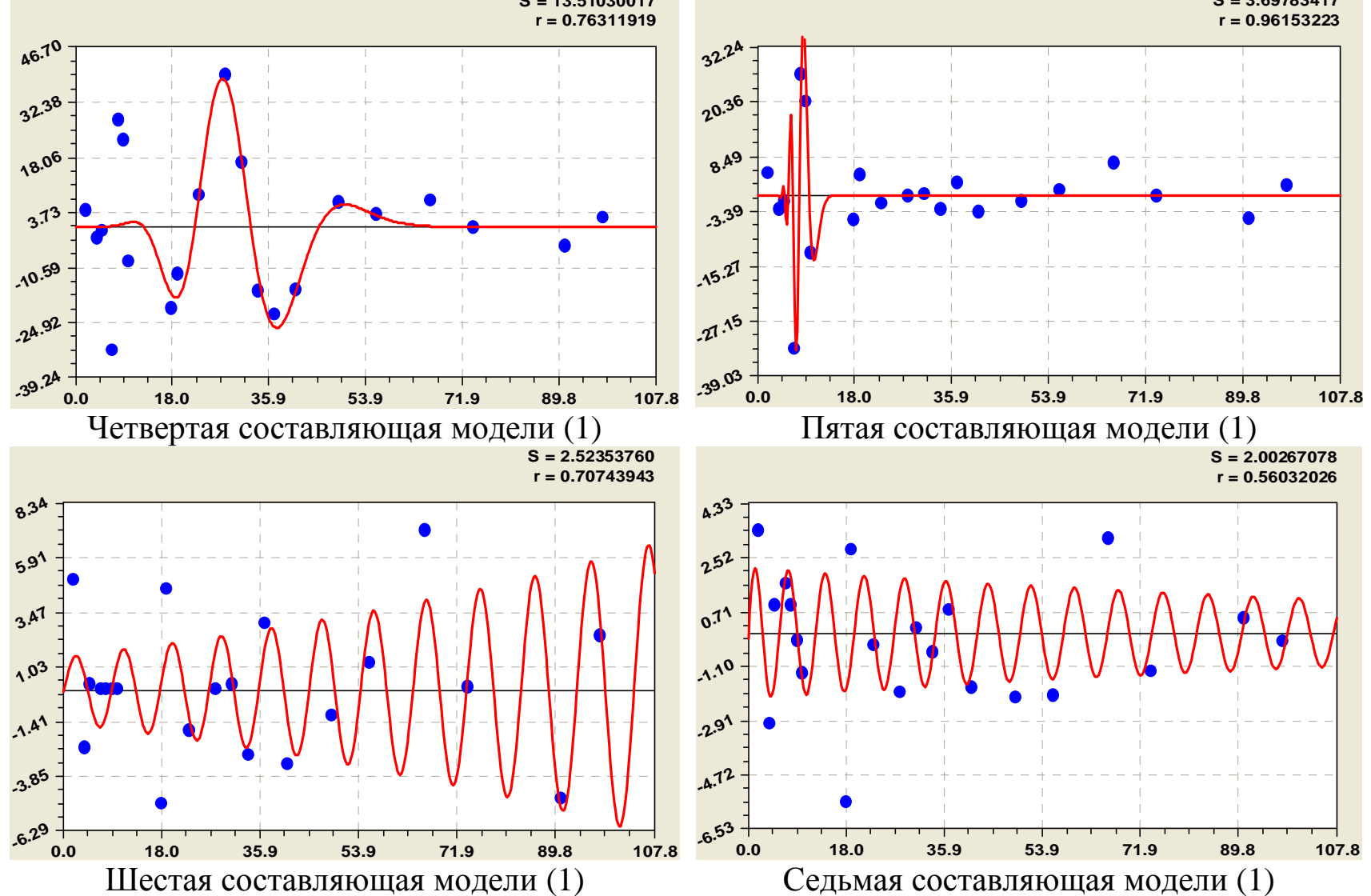

Пятая составляющая модели (1)

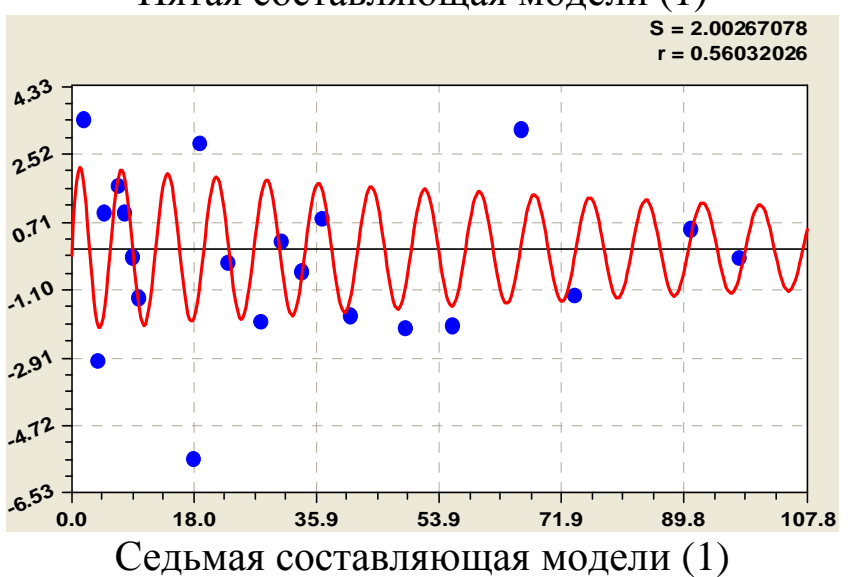

Рис. 2. Волновые возмущения уровня реки в весеннее половодье

Причем дополнительными уравнениями, начиная с четвертой составляющей, вполне можно показать небольшое снижение уровня воды в пике половодья (какое-то водное явление импульсно повлияло на частичное снижение уровня воды в реке).

Загрязнение участка Волги. Динамика нарастания загрязнения [4-12] на примере реки Волга покажем в двух точках забора проб речной воды: а) выше г. Волжска, расположенного на территории Республики Марий Эл; б) в черте г. Зеленодольска на территории Республики Татарстан. Данные анализа проб речной воды Волги с 1988 по 2006 гг. были промоделированы биотехническим законом [2-12].

За начало отсчета принята дата 01.01.1988 и для неё соблюдается условие $t=0$. 
После идентификации устойчивого закона для концентрации сульфатов были получены формулы (рис. 3) трендов динамики загрязнений от г. Волжска и г. Зеленодольска:

- в точке забора проб воды из Волги выше г. Волжска (РМЭ)

$$
\begin{aligned}
& \text { Сульфаты }=78,8878 \exp \left(3,5096 \cdot 10^{-5} t^{1,03603}\right)+ \\
& +1,4860 \cdot 10^{-70} t^{24,33858} \exp \left(-0,010278 t^{1,00068}\right) ;
\end{aligned}
$$

- в точке забора проб речной воды из Волги в черте г. Зеленодольска (РТ)

$$
\text { Сульфатьл }=107,094 \exp \left(-1,48646 \cdot 10^{-5} t\right) \text {. }
$$

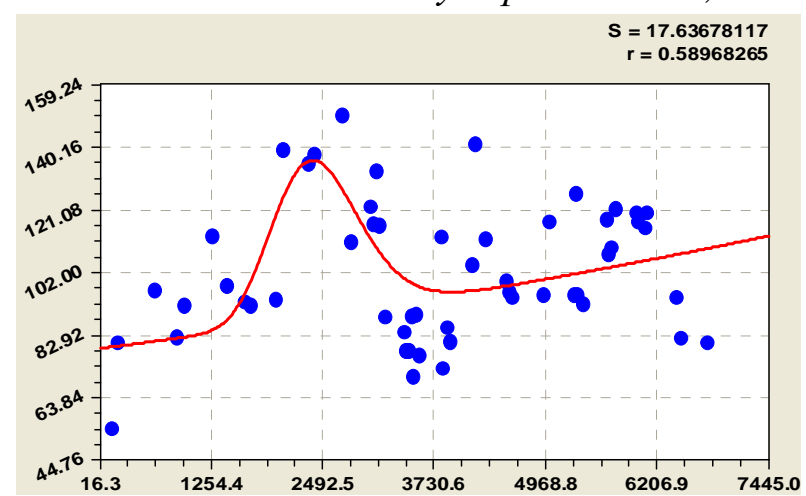

a)

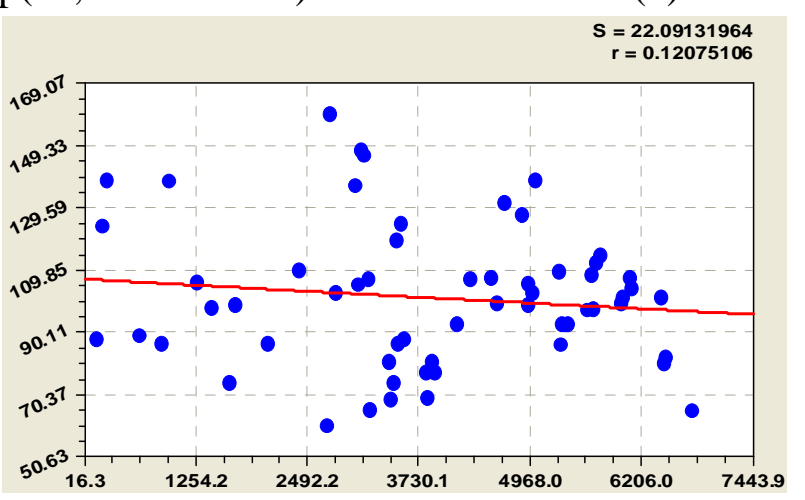

б)

Рис. 3. Динамика загрязнения речной воды Волги в точках взятия проб на сульфаты: a - до города Волжска; б- в черте города Зеленодольск

Идентификацией биотехнического закона по данным анализа на динамику концентрации общего железа в речной воде получились формулы (рис. 4):

a)

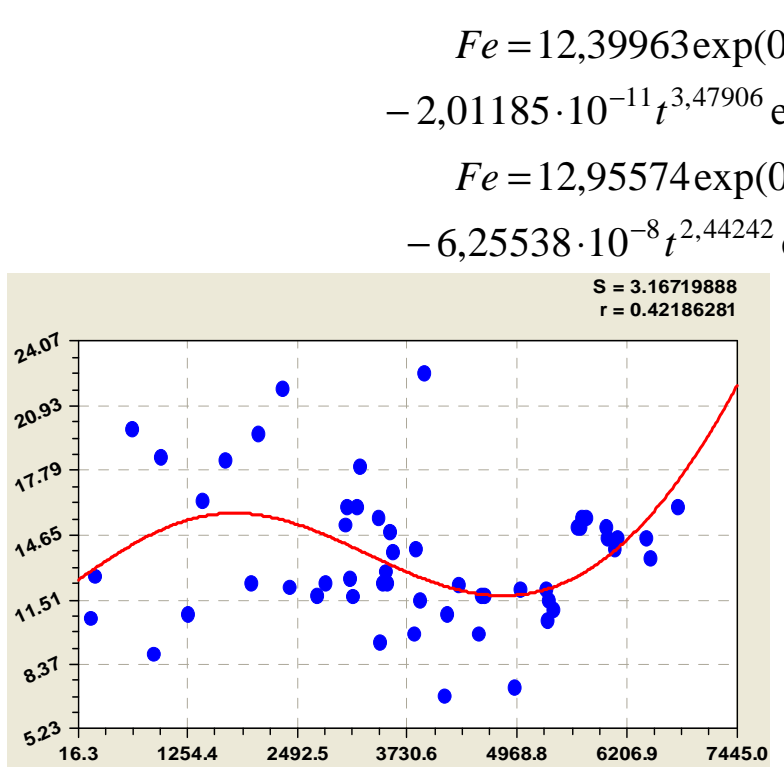

Рис. 4. Динамика загрязнения речной воды Волги в точках взятия проб на железо: a - до города Волжска; б- в черте города Зеленодольск

Моделирование в среде CurveExpert-1.3 по данным анализа на концентрацию азота аммонийного в речной воде дало формулы (рис. 5):

$$
\begin{gathered}
N H_{3}=0,37766 \exp \left(0,00025736 t^{0,98867}\right)-3,86651 \cdot 10^{-10} t^{2,64063} \exp \left(-0,00012686 t^{1,03751}\right) ; \\
N H_{3}=0,41264 \exp \left(0,00028974 t^{0,99559}\right)-5,78866 \cdot 10^{-8} t^{1,99328}
\end{gathered}
$$




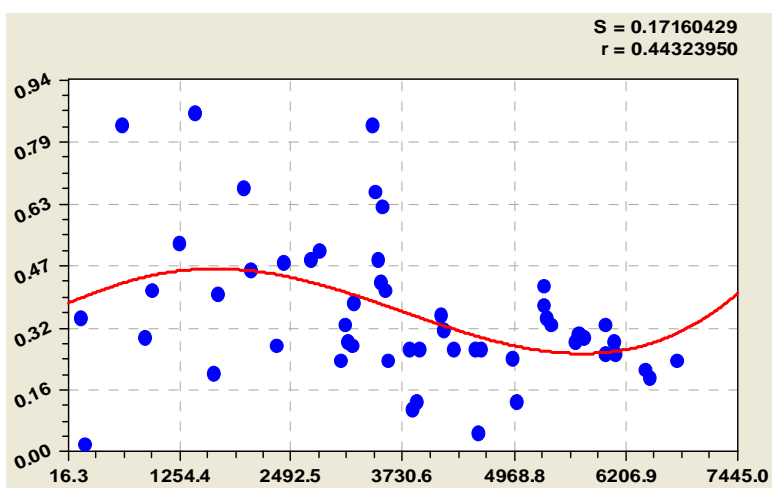

a)

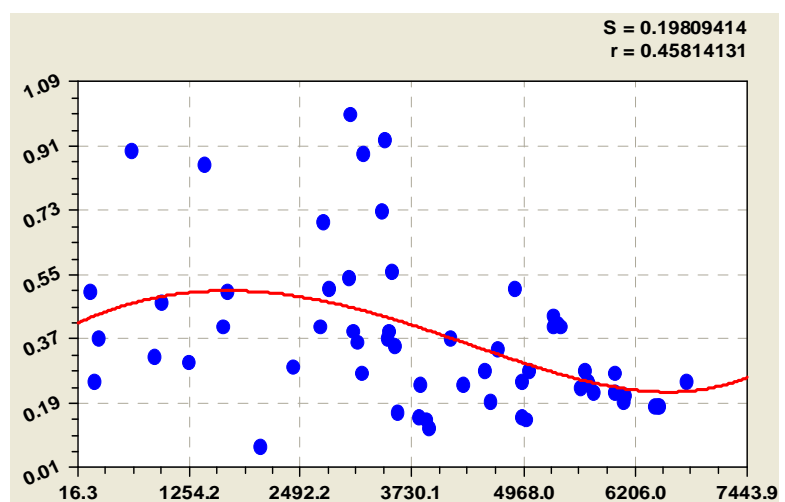

б)

Рис. 5. Динамика загрязнения воды Волги в точках взятия проб на азот аммонийный: а - до города Волжска; б- в черте города Зеленодольск

Было доказано, что отчетные данные - средние за месяц и год - надо дополнять моделями поведения реки Волга на различных участках водотоков по суткам. Для этого журналы исходных данных нужно заполнять по отдельным постоянным или переменным (с указанием координат) точкам взятия проб речной воды. Анализ на одну дату по всем замерам загрязнения позволит получать картины распределения загрязняющих веществ по длине и створам.

Многолетняя динамика загрязнения притока Волги. На притоке Волги по нашему патенту [10] в черте г. Йошкар-Ола были проведены замеры показателей загрязнения реки М. Кокшага. График изменения обобщенного показателя загрязненности (ОПЗ) по пробам речной воды в 2004-2005 гг. (за начало координат $t=0$ принято начало половодья 16.04.2004) для створов канализационных стоков изменяется (рис. 6) по формуле [9]:

$$
O \Pi 3=O \Pi 3_{1}+O \Pi 3_{2}+O \Pi 3_{3}
$$

ОП $3_{1}=2,62220 \exp (0,0034928 t), O \Pi 3_{2}=A_{1} \cos (\pi t / 5,89034-2,66109)$,

$A_{1}=4,79564 \exp (0,00065798 t), O \Pi 3_{3}=A_{2} \cos \left(\pi t / p_{2}-0,83795\right)$,

$A_{2}=8,36698 \exp (0,00028212 t), p_{2}=246,827-0,27331 t$,

где $О П 3_{1}$ - тренд показателя по суткам за два учетных года; $O П 3_{2}$ - быстрые изменения показателя с периодом в $2 \times 5,89034 \approx 12$ суток; $О П 3_{3}$ - долговременные изменения качества речной воды с начальным периодом $2 \times 246,827 \approx 494$ суток; $A_{1}, A_{2}$ - амплитуда (половина)

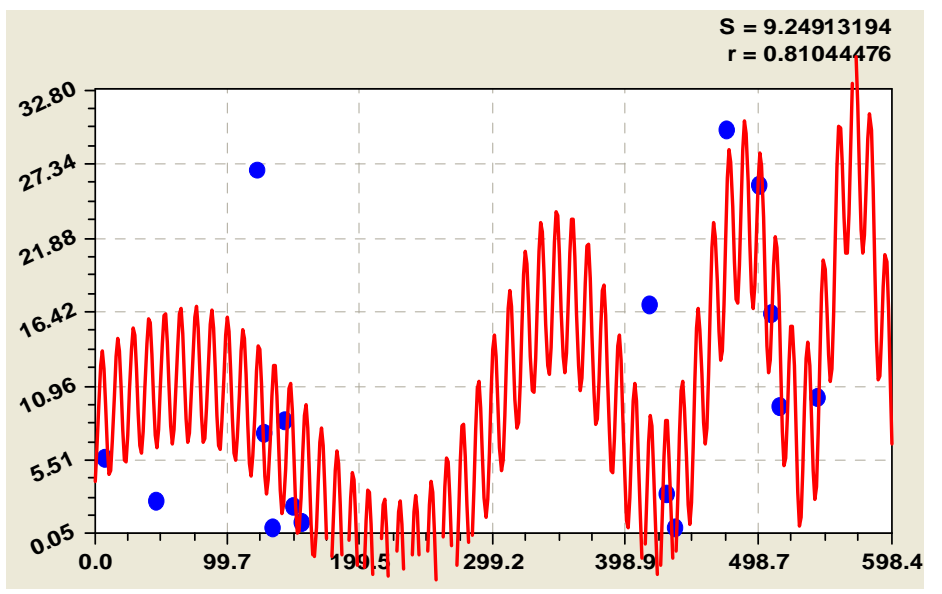

колебательного возмущения показателя по волновым составляющим статистической модели (8); $p_{1}=5,89034, p_{2}$ половина периода колебательного возмущения по двум колебаниям.

Рис. 6. Динамика ОПЗ за 2004-05 гг. канализационного загрязнения воды реки Малая Кокшага по модели (8) 
Все три составляющие (8) имеют амплитуду волны по закону экспоненциального роста (первая составляющая показывает только малую часть более длинной волны, намного превышающей период измерений). Это указывает на снижение влияния канализационных стоков г. Йошкар-Олы и улучшение качества речной воды за период времени в 558 суток.

Загрязнение притока М. Когшаги населенными пунктами. Протяженность исследуемых участков реки Б. Ошла, впадающей в М. Кокшагу перед Йошкар-олинским водозабором, составляет 44 км, при этом имеются шесть пунктов наблюдения. Для 2004 г. были получены статистические закономерности концентрации различных загрязняющих веществ в зависимости от расстояний от истока до точек наблюдения и вплоть до устья малой реки.

Насаленные пункты меняют скачками концентрацию загрязняющих веществ в речной воде и появляется возможность оценивать моделями очищающей способности самой реки.

Водородный показатель $p H$ вдоль реки Б. Ошла от истока до устья впадения в М. Кокшагу (около г. Йошкар-Ола) изменяется по формуле (рис. 1) по расстояниям $L$ (км)

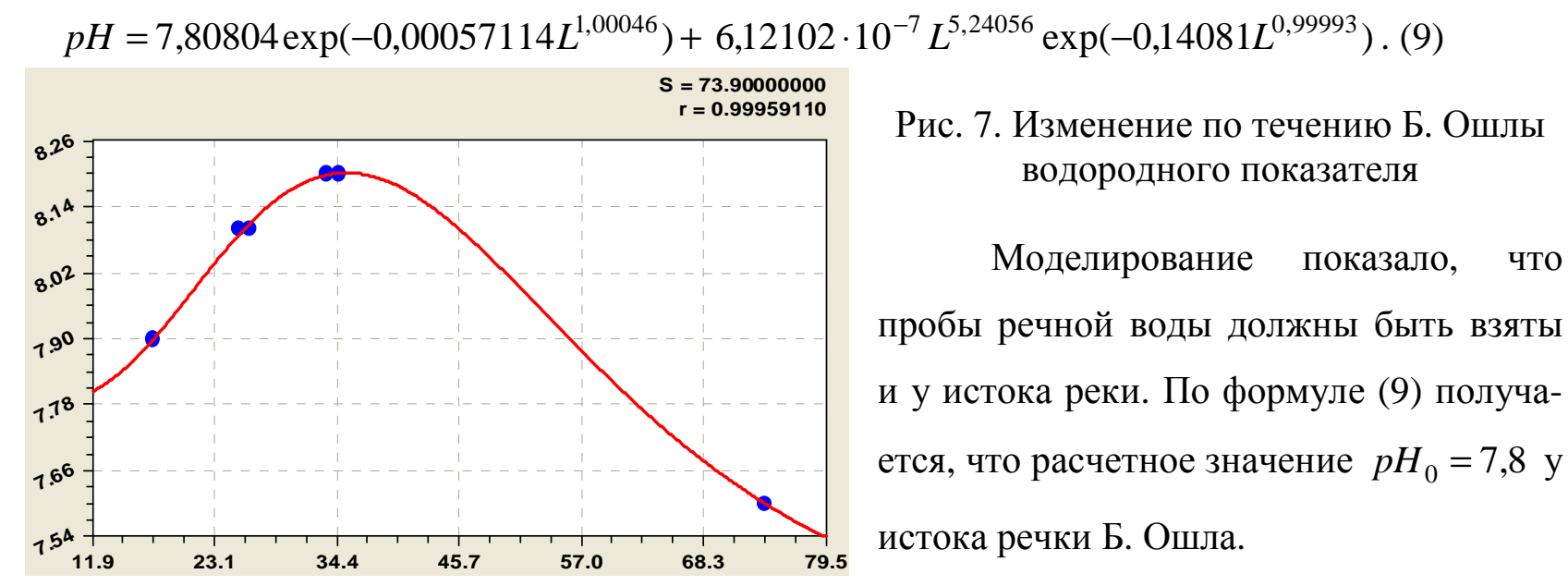

Первая составляющая формулы (9) показывает естественную способность реки к самоочищению от истока до устья, а вторая составляющая характеризует влияние поселений и других мест загрязнения реки на водородный показатель.

Нефтепродукты в среднем (рис. 8) по реке Б. Ошла изменяются по формуле

$$
\text { нефтепродукты }=4,7517 \cdot 10^{-7} L^{5,52622} \exp \left(-0,34937 L^{0,83164}\right) \text {. }
$$

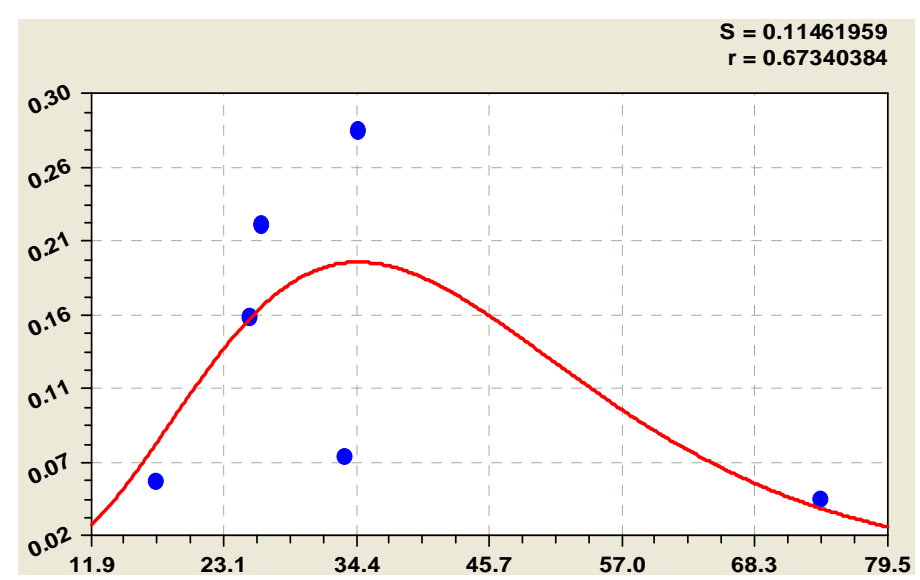

Рис. 8. Изменение по течению

Б. Ошлы нефтепродуктов

Из распределения роя точек на рис. 8 видно, что возможны две версии отклонений от тренда: 1) замеры проведены неточно; 2) между Туршой и Люлпанами происходит самоочищение реки. 
В Головино было проведено только одно измерение, что явно недостаточно.

Лучше выглядит график на рис. 9 изменения марганца вдоль реки по формуле

$$
M n=7,32544 \cdot 10^{-9} L^{14,00647} \exp \left(-6,50298 L^{0,44669}\right) .
$$
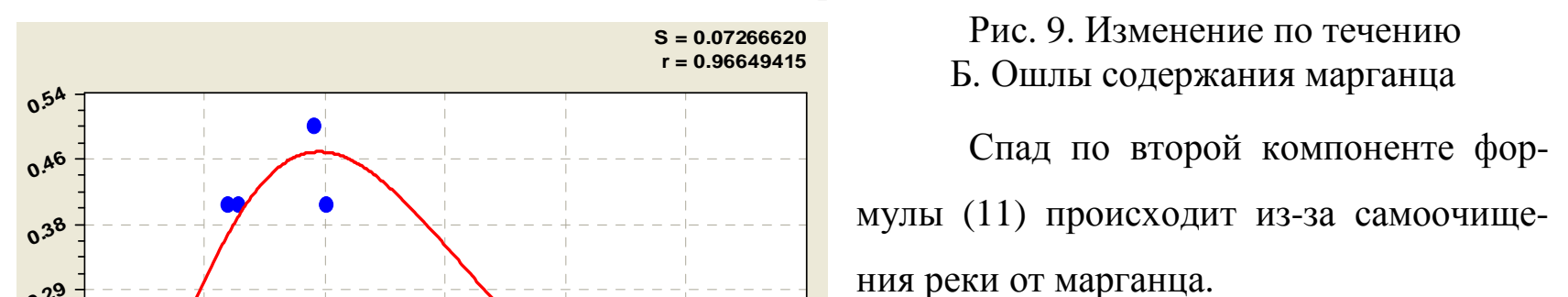

С высокой активностью изменяет-

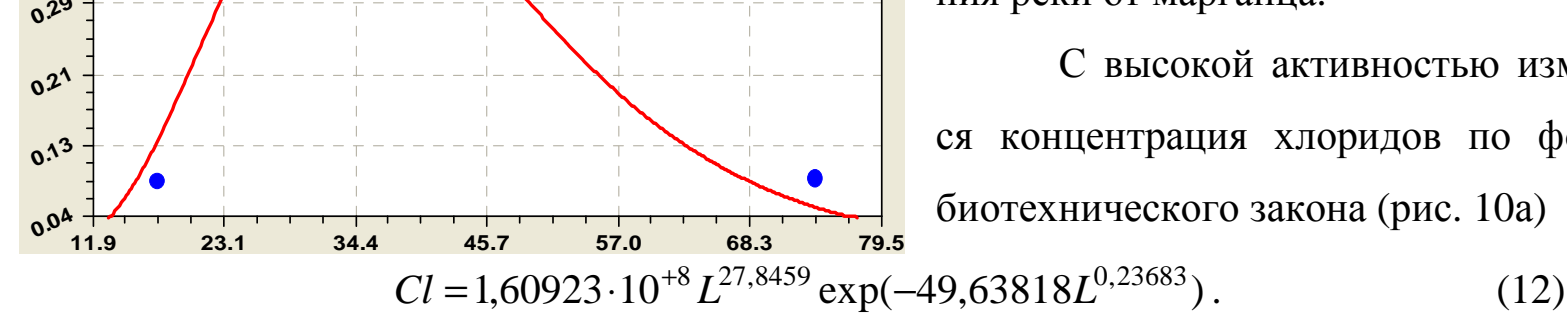

Нитраты изменяются вдоль реки Б. Ошла по закономерности (рис. 10б)

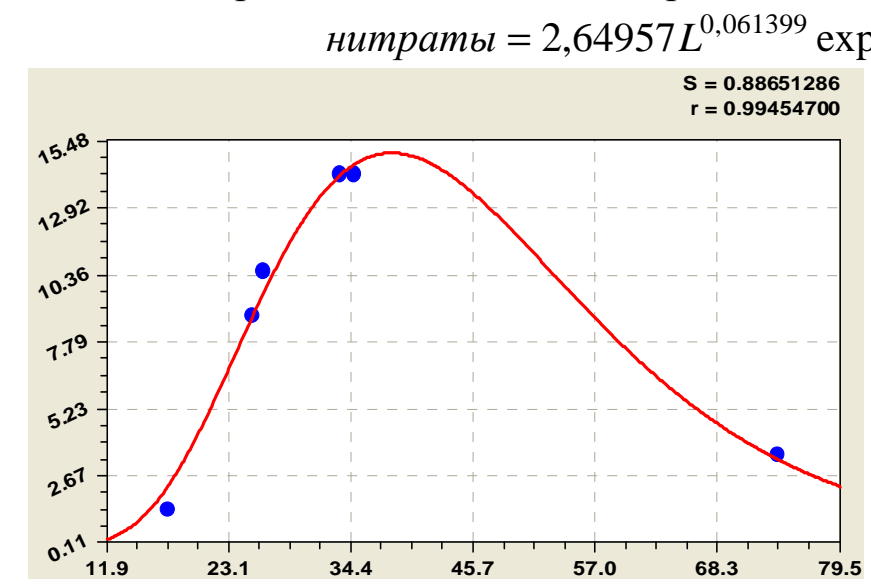

a) $\exp \left(-3,78835 \cdot 10^{-5} L^{2,10370}\right)$.

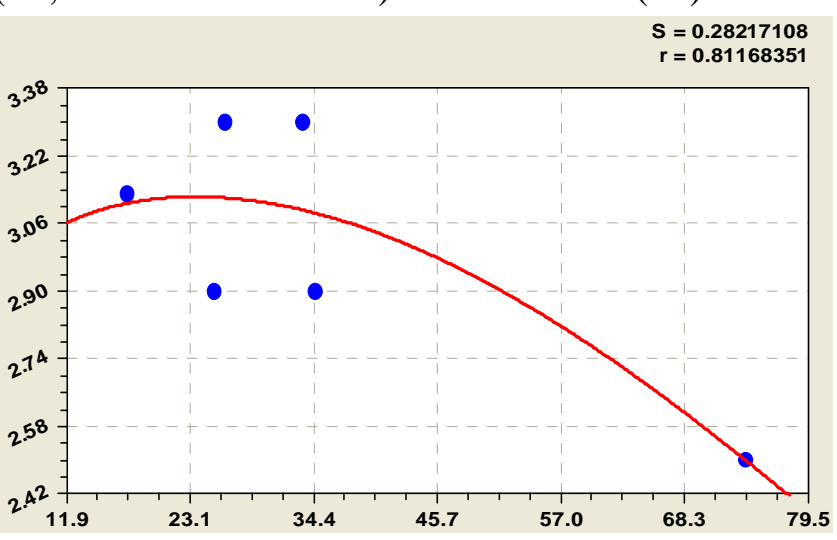

б)

Рис. 10. Изменение по течению Б. Ошлы содержания хлоридов (а) и нитратов (б)

Изменение сульфатов похоже на (9), но с медленным спадом первой части (рис. 11a), что указывает на опасность Йошкар-олинскому водозабору (рис. 11) по выражению

$$
\text { сульфаты }=30,1650 \exp (-0,00061467 t)-1,6505 \cdot 10^{+9} L^{65,8883} \exp \left(-95,65252 L^{0,27295}\right) \text {. }
$$

Аналогично ведут себя взвешенные вещества (рис. 11б) по закономерности

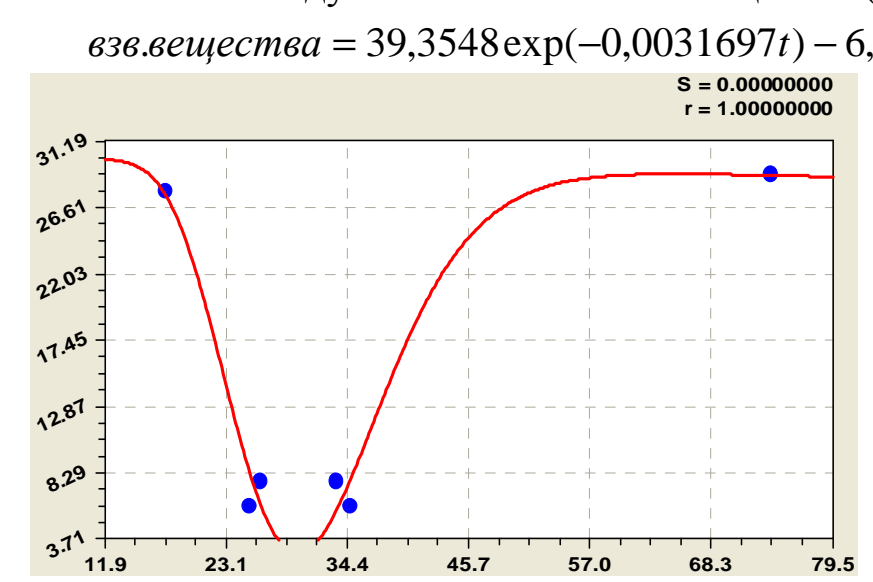

a)

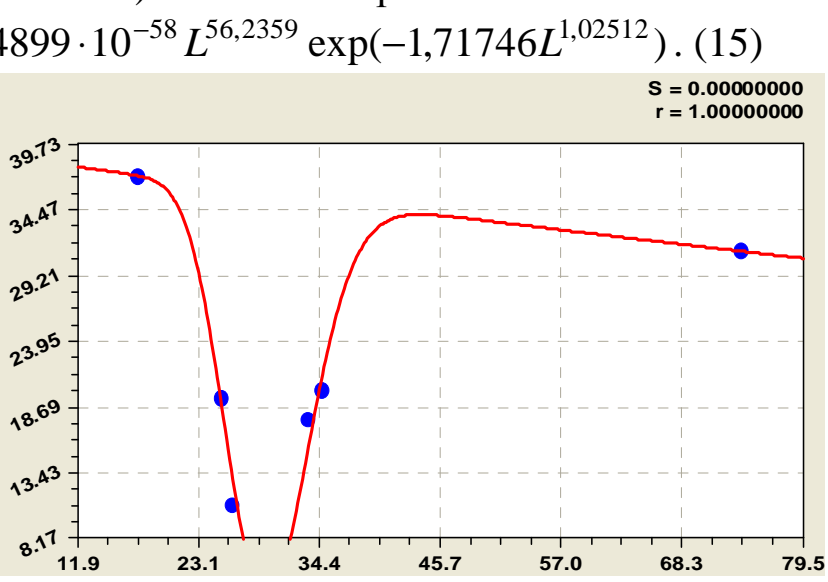

б)

Рис. 11. Изменение по течению Б. Ошлы сульфатов (а) и взвешенных веществ (б) 
Фосфаты (рис. 12а) и БПК 5 (рис. 12б) изменяются по формулам:

$$
\begin{gathered}
\text { фocфambl }=2,81289 \cdot 10^{-5} L^{3,24723} \exp \left(-0,093495 L^{1,00360}\right) ; \\
\text { БПK } K_{5}=0,034294 L^{1,64225} \exp (-0,043249 L) .
\end{gathered}
$$

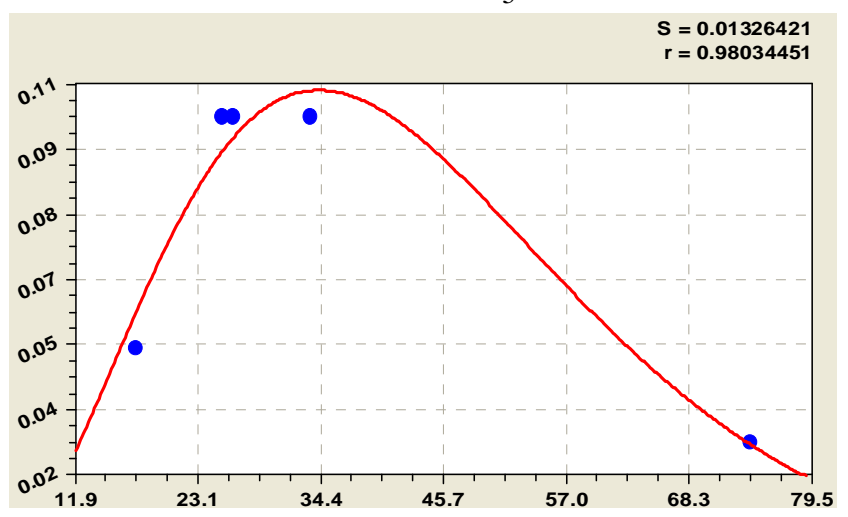

a)

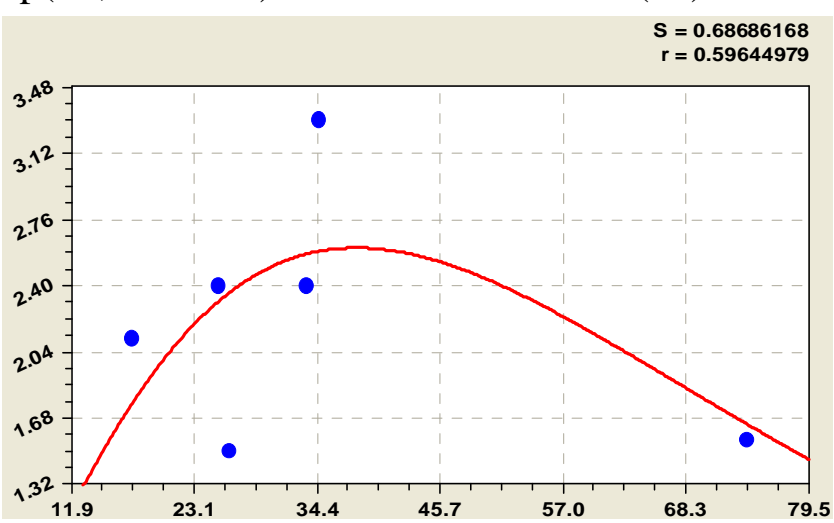

б)

Рис. 12. Изменение по течению Б. Ошлы фосфатов (а) и концентрации БПК $(б)$

Сухой остаток (рис. 13a) и обобщенный показатель ИЗВ (рис. 13б) имеют формулы:

$$
\begin{gathered}
\text { сух.остаток }=637859,2 L^{2,11967} \exp \left(-9,57405 L^{0,13121}\right) ; \\
\text { ИЗВ }=13851144,0 L^{18,29818} \exp \left(-35,02234 L^{0,22900}\right) .
\end{gathered}
$$

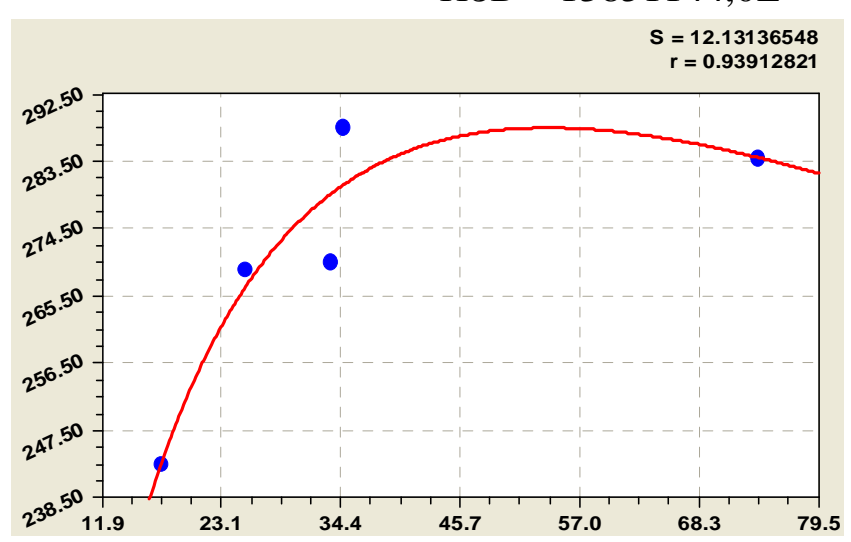

a)

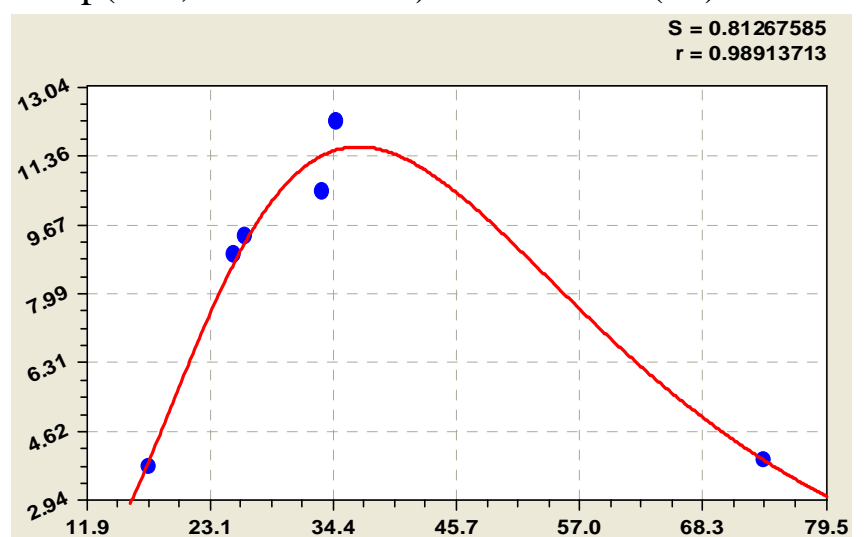

б)

Рис. 13. Изменение по течению Б. Ошлы сухих остатков (а) и показателя ИЗВ (б)

По показателю ИЗВ возбудителем волнового возмущения в концентрации множества видов загрязнения является на реке Б. Ошла третий населенный пункт - БОС Люльпаны. Выше него, в точке забора проб речной воды, максимальная относительная погрешность отклонения измеренного ИЗВ от расчетного составляет 8,40 \%. С увеличением количества точек взятия проб речной воды, причем непосредственно и у истока реки, появится возможность оценки вклада каждого из учтенных поселений на качество водопользования.

Годичная динамика загрязнения до городского водозабора. По данным 2002 г. рассмотрим модель динамики на примере водородного показателя рН (остальные виды загрязнения моделируются по методу [3] аналогично) в постоянной точке взятия проб службой «Водоканал» г. Йошкар-Олы перед городским водозабором. От него речной водой снабжается более трети от общей потребности города. Начало отсчета $t=0$ для даты 01.01.2002.

Первые два члена (рис. 14) статистической модели имеют вид 


$$
p H=\sum_{i=1}^{m} p H_{i}
$$

$p H_{1}=7,58279 \exp \left(-8,88999 \cdot 10^{-6} t^{1,70524}\right), p H_{2}=A_{1} \cos \left(\pi t / p_{1}+0,17581\right)$,

$A_{1}=-0,12952 \exp \left(0,00075797 t^{1,48018}\right) \cdot p_{2}=1,46723+0,061221 t^{1,02376}$.

$\mathrm{S}=\mathbf{0 . 2 5 1 6 5 0 7 4}$ $r=0.73795939$

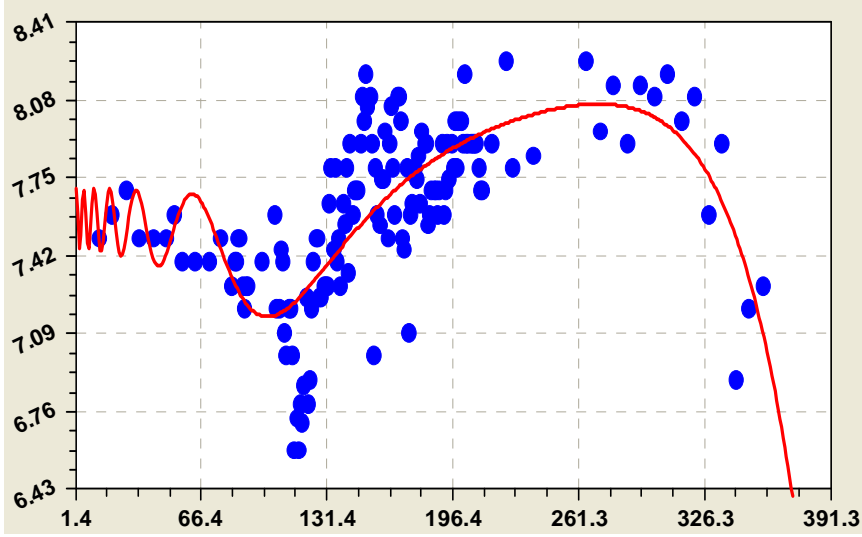

Рис. 14. График по первым двум составляющим статистической модели динамики водородного показателя перед городским водозабором г. Йошкар-Олы

По 147 измеренным в одном году значениям $p H$ рой точек расположился так, как показано на рис. 14. График показывает, что с приближением весны загрязнение ведет себя как сжатая пружина.

Любая составляющая в формуле (20), если количество $i$ составляющих больше двух, может быть записана в виде асимметричной вейвлет-функции [5-9] уединенного сигнала

$$
p H_{i}=A_{i} \cos \left(\pi / p_{i}-a_{8}\right), A_{i}=a_{1} t^{a_{2}} \exp \left(-a_{3} t^{a_{4}}\right), p_{i}=a_{5}+a_{6} t^{a_{7}},
$$

где $t$ - время с момента начал измерений, в данном примере с 01.01.2002, сутки,

$a_{1} \ldots a_{8}$ - параметры череды гидрометеорологических и иных сигналов по модели (21).

В табл. 1 приведены параметры модели типа $p H_{i}=f(t)$ по значимым составляющим.

Поиск составляющих завершается с приближением остатков к точности измерений.

Таблица 1

Параметры сигнала (21) динамики водородного показателя в 2002 г.

\begin{tabular}{|c|c|c|c|c|c|c|c|c|}
\hline \multirow{2}{*}{$\begin{array}{c}\text { № } \\
i\end{array}$} & \multicolumn{6}{|c|}{ Значения параметров статистической модели из асимметричных вейвлет-функций } \\
\cline { 2 - 9 } & $a_{1}$ & $a_{2}$ & $a_{3}$ & $a_{4}$ & $a_{5}$ & $a_{6}$ & $a_{7}$ & $a_{8}$ \\
\hline 1 & 7.58279 & 0 & $8.88999 \mathrm{e}-6$ & 1.70524 & 0 & 0 & 0 & 0 \\
\hline 2 & -0.12592 & 0 & 0.00075797 & 1.48018 & 1.46723 & 0.061221 & 1.02376 & -0.17581 \\
\hline 3 & $-2.7230 \mathrm{e}-25$ & 14.79865 & 0.17946 & 0.93053 & 14.3024 & 0.00043597 & 1.85606 & -3.68825 \\
\hline 4 & $-8.15626 \mathrm{e}-8$ & 3.51281 & 0.29143 & 0.79991 & 1.45561 & 0.022370 & 1.19064 & 5.42908 \\
\hline 5 & $-2.1458 \mathrm{e}-25$ & 14.99252 & 0.18290 & 0.94192 & 14.86714 & -0.00019737 & 1.83443 & 2.00279 \\
\hline 6 & $9.0721 \mathrm{e}-71$ & 39.88342 & 0.35418 & 0.94598 & 4.14735 & 0.0018262 & 1.27544 & -3.68641 \\
\hline 7 & $-5.7993 \mathrm{e}-88$ & 44.78259 & 0.19321 & 0.99983 & 54.7116 & -0.14008 & 0.99995 & -4.47964 \\
\hline 8 & $-3.3084 \mathrm{e}-102$ & 50.44087 & 0.18008 & 1.00691 & 5.12094 & 0.023203 & 0.99756 & 1.43738 \\
\hline 9 & $-1.1532 \mathrm{e}-51$ & 27.99035 & 0.10925 & 1.09361 & 12.8979 & 0.0068739 & 1.14933 & 4.57318 \\
\hline 10 & $2.86279 \mathrm{e}-65$ & 33.72585 & 0.15331 & 0.99987 & 298.752 & 0.85891 & 1.00044 & -0.24634 \\
\hline 11 & 0.014863 & 0.86425 & 0.39659 & 0.40436 & 2.84994 & 0.0055964 & 1.05753 & 2.08456 \\
\hline 12 & $6.0359 \mathrm{e}-43$ & 25.81854 & 0.16123 & 1.08484 & 2.87202 & -0.00018127 & 1.16910 & 1.29391 \\
\hline 13 & $2.3651 \mathrm{e}-21$ & 11.63230 & 0.085858 & 1.00481 & 2.02362 & 0 & 0 & -0.88415 \\
\hline
\end{tabular}

После третьей составляющей оказалось, что внизу резко выделяются три точки (из-за залповых сбросов загрязнений в реку). Эти точки были в дальнейшем исключены. Из рис. 15 
видно, что седьмая и восьмая составляющие «разорвали» летнюю межень. Поэтому с девятой составляющей модель показывает динамику $\mathrm{pH}$ от зимней межени до летней межени.
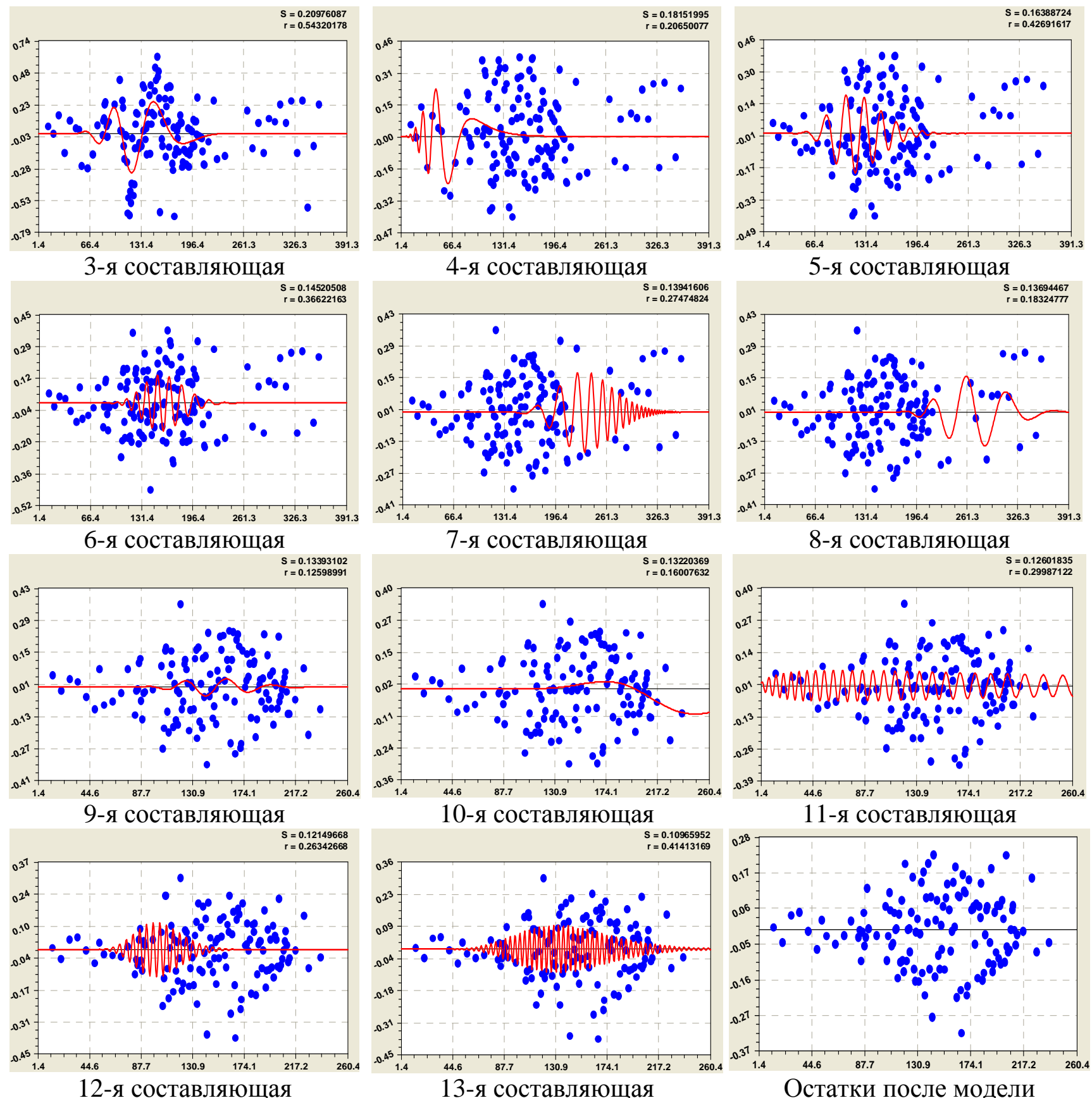

12-я составляющая

13-я составляющая

Остатки после модели

Рис. 15. Графики вейвлет-сигналов суточной динамики водородного показателя

Максимальное значение остатков достигает после всех вывяленных 13 составляющих $p H=0,3$. Поэтому возможны и последующие волновые составляющие, но они уже будут показывать возмущения в конце весеннего половодья.

Известные методы гидрологических и санитарно-эпидемиологических расчетов требуют определения максимальных значений параметров загрязнения.

По максимуму значений водородного показателя (рис. 16) была получена формула

$$
p H_{\max }=7,65408 \exp \left(-6,05556 \cdot 10^{-5} t^{1,53810}\right)+4,68627 \cdot 10^{-8} t^{3,77261} \exp \left(-0,012820 t^{0,98619}\right) \text {. }
$$




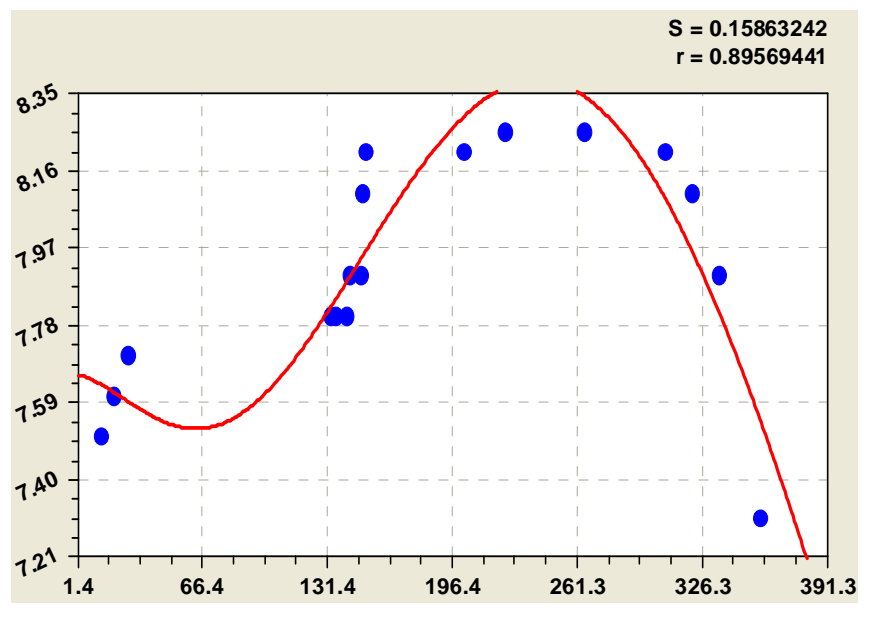

Рис. 16. График модели по максимальным значениям годичной динамики $p H$

перед городским водозабором

Выводы. Сравнение с динамикой уровня реки показывает различный лаг запаздывания у видов загрязнения. Тогда грубыми расчетами от измеренных в данном году уровней можно дать прогноз на следующий год по максимумам загрязнения при условии, что до следующего паводка не будут приянты меры по снижению сбросов.

Выявление закономерностей загрязнения от истока до устья малых притоков позволит в последующем создать электронные карты и ГИС и по главной реке Волге.

\section{Литература}

1. Практикум по курсу прикладной геодезии / Н.Н. Лебедев, В.Е. Новак, Г.П. Левчук и др. Под ред. Н.Н. Лебедева. - М.: Недра, 1977. -384 с.

2. Мазуркин, П.М. Статистическая гидрология / П.М. Мазуркин, В.И. Зверев, А.И. Толстухин. - Учебное пособие. - Йошкар-Ола: МарГТУ, 2002. - 274 с.

3. Мазуркин, П.М. Математическое моделирование. Идентификация однофакторных статистических закономерностей: Учебное пособие / П.М. Мазуркин, А.С. Филонов. - ЙошкарОла: МарГТУ, 2006. - 292 с.

4. Мазуркин, П.М. Закономерности загрязнения природы / П.М. Мазуркин, Е.А. Щербакова: Научное издание. - Йошкар-Ола: МарГТУ, 2002. - 62 с.

5. Мазуркин, П.М. Статистическая экология / П.М. Мазуркин: Учебное пособие. - ЙошкарОла: МарГТУ, 2004. - 308 с.

6. Мазуркин, П.М. Геоэкология: Закономерности современного естествознания: Научное изд. / П.М. Мазуркин. - Йошкар-Ола: МарГТУ, 2006. - 336 с.

7. Иванов, А.А. Экологическая оценка водосборов малых рек (на примере Республики Марий Эл): Научное издание / А.А. Иванов, П.М. Мазуркин. - Йошкар-Ола: МарГТУ, 2007. - 108 с.

8. Мазуркин, П.М. Рациональное природопользование: учебное пособие. В 3-х ч. Ч. 2: Экологически ответственное водопользование / П.М. Мазуркин, С.Е. Анисимов, С.И. Михайлова; под ред. П.М. Мазуркина. - Йошкар-Ола: МарГТУ, 2006. - 216 с.

9. Мазуркин, П.М. Определение экологического состояния речной воды по обобщенному показателю загрязненности / П.М. Мазуркин, А.М. Сибагатуллина // Водное хозяйство России. - 2008. - № 1. - С.37-46.

10. Пат. 2269775 Российская Федерация, МПК G 01 N 33/18 (2006.01) G 01 N 21/64 (2006.01). Способ измерения загрязнения реки сточными водами / Мазуркин П.М., Андреева Л.Г., Иванова Т.А., Сибагатуллина А.М., Абрамова Е.В., Гончарова Ж.А., Моисеева Т.А. (РФ); заявитель и патентообладатель Марийск. гос. тех. ун-т. - №2004105902/12; заявл. 27.02.04; опубл. 10.02.06, Бюл. № 4.

11. Пат. 2293290 Российская Федерация, МПК G 01 C 13/00 (2006.01). Способ измерения площади водосбора реки по длине и падению притоков / Мазуркин П.М., Иванов А.А., Михайлова С.И., Волкова Л.О. (РФ); заявитель и патентообладатель Марийск. гос. тех. ун-т. №2005101055/28; заявл. 18.01.2005; опубл. 10.02.2007, Бюл. № 4.

12. Солдатова, В.А. Динамика твердых отходов: Научное издание / В.А. Солдатова, П.М. Мазуркин. Под ред. проф. П.М. Мазуркина. - Чебоксары: МАДИ (ГТУ), Волжский филиал, 2006. -257 c. 